\title{
Criteria and scoring method for evaluation of dairy cattle enterprises in terms of biosecurity and animal welfare conditions
}

\author{
Durhasan MUNDAN ${ }^{1}$, Yahya ÖZTÜRK²
}

${ }^{1}$ Harran University, Faculty of Veterinary Medicine, Department of Animal Science, Sanliurfa/TURKEY

${ }^{2}$ Mehmet Akif Ersoy University, Burdur Vocational School of Food, Agriculture and Livestock, Department of Food Processing, Burdur/TURKEY

\section{Key Words: \\ biosecurity \\ cow comfort \\ economic impact \\ scoring method \\ welfare levels}

\section{Anahtar Kelimeler: \\ biyogüvenlik \\ inek konforu \\ ekonomik etki \\ puanlama metodları \\ refah düzeyleri}

Received: 28.03.2019

Accepted: 14.05.2019

Published Online: 30.06.2019

Article Code: 546062

Correspondence:

D. MUNDAN

(durhasanmundan@gmail.com)

ORCID:

D. MUNDAN: 0000-0002-9503-9850

Y. ÖZTÜRK: 0000-0003-0376-0868

\begin{abstract}
In this review, it is aimed to determine the criteria to be used in the evaluation of cow comfort and biosecurity rules, determination of application level of criteria and as a result, what required preventive will be taken in dairy cattle enterprises. These criteria are determined and measured by scientific variables. In this study, 40 criteria were determined to measure biosecurity and animal welfare in livestock enterprises. Biosecurity criteria and animal welfare standards are used to evaluate the quality and security of dairy cattle enterprises. The evaluation of these criteria is important for easy applicability. The necessary prevention will be taken by reporting the cost of the negative criteria to the farmers and thus the scoring of the enterprise will reach the highest level. It is important to obtain a high score from this evaluation, to have the licensing of the enterprises and the certificate of the disease-free enterprises.
\end{abstract}

Süt sığırı işletmelerinin biyogüvenlik ve hayvan refahı koşulları açısından değerlendirilmesinde kullanılacak kriterler ve puanlama yöntemi

\section{ÖZ}

Bu derlemede, süt sığırı işletmelerinde biyogüvenlik kuralları ve inek konforunun değerlendirilmesinde kullanılacak ölçütlerin belirlenmesi, ölçütlerin uygulama seviyesinin tespiti ve bunun neticesinde alınmas1 gerekli tedbirlerin neler olacağı amaçlanmaktadır. Bu ölçütler, bilimsel değişkenler ile belirlenmekte ve ölçülmektedir. Bu çalışmada, hayvancılık işletmelerinde biyogüvenlik ve hayvan refahının ölçülebilmesi için 40 ölçüt belirlenmiştir. Biyogüvenlik kriterleri ve hayvan refahı standartları, süt sığırı işletmelerinin kalite ve güvenliğini değerlendirmek amacıyla kullanılmaktadır. Bu kriterlerin değerlendirilmesi, kolay uygulanabilirliği açısından önem taşımaktadır. Negatif ölçütlere ait maliyetin yetiştiriciye bildirilmesi ile gerekli tedbirler alınacak ve böylece işletmenin puanı en üst seviyeye ulaşacaktır. Bu değerlendirmeden yüksek puan almak, işletmenin ruhsatlandırılması ve hastalıktan arî belgesine sahip olması açısından önem arz etmektedir.

\section{INTRODUCTION}

Nowadays, large-capacity dairy cattle farms have gained a modern structure. Milk production in animal breeding has an intensive structure that requires, capital and technology. This type of production always requires actual knowledge, technological developments and in-service training. In animal production, sustainability is necessary, also the minimization of the risk factors is important in terms of sustainability. If preventive medicine cannot be administered, diseases and problems will arise. There are 4 types of livestock breeding in enterprises. These are intensive livestock breeding, integrated livestock breeding, organic livestock breeding and industrial livestock breeding (1).

Registered livestock enterprises, having a quarantine unit and minimum technical and hygienic conditions as well as animals which have been determined not to carry diseases such as foot-mouth disease, tuberculosis and brucellosis based on laboratory tests in accordance with regulations are defined as "disease-free enterprises" (2).
EU states have updated standards relating to animal welfare and have implemented in directive 93/119/EC of 1993. EU countries and developed countries bring standards in terms of animal welfare in addition to animal health. In Turkey, animal welfare standards are taken into consideration for livestock enterprises to have EU approval number (3). The "Communique on the supply of raw milk" prepared by the Ministry of Food, Agriculture and Livestock was published in the Official Gazette dated April 27, 2017 and numbered 30050 and entered into force. With this communique, the selling criteria of raw milk were determined.

\section{Biosecurity criteria in enterprises:}

The EU has adopted its approach the "2007-2013 Animal Health Strategy" and "Prevention is better than treatment" in animal health policy. With this strategy, the European Commission completed the draft revising existing animal health legislation on 6 May 2013 (4). Diseases increase the cost in enterprises and dairy industries with productivity losses and veterinary health expenses. Therefore, biosecurity criteria and 
animal welfare standards are used to remove disease agent and control the quality and security of dairy cattle farms.

Providing of healthy and highly yielding breeding animals, ideal barn, correct care-nutrition and herd health management are required to make a profitable livestock breeding. All of these substances have biosecurity and animal welfare criteria. Preventive medicine applications include the very important section of herd health management. Today, biosecurity rules are applied with the aim of prevention against diseases in livestock enterprises. These rules (5);

1. Ensuring healthy living conditions

2. Keeping away the disease agent

\section{Hygiene}

\section{Strengthening the immune system}

5. Providing knowledgeable, experienced and reliable personnel

Healthy living conditions can be provided by improving of living standard, the environmental conditions inside the barn and the care-nutrition. Improvement of environmental conditions inside the barn (ventilation, lighting, temperature, relative humidity) is important in terms of improving living standards and ensuring healthy living conditions. To ensure healthy living conditions, it is necessary to measure the temperature $\mathrm{x}$ humidity index (THI) in barn. These measurements can be made using thermometer and hygrometer equipment. Correct nutrition, obtained by improving the feeding, is important in terms of ensuring healthy living conditions. Body condition score (BCS) in cows is an indication of correct feeding. Longed periods of high air temperature coupled with high relative humidity affects the feed intake, milk production, and reproductive efficiency in dairy animal and consequently reducing profitability for dairy farmers (1).

It is important to remove disease agents such as microorganisms, bacteria, viruses, fungi, parasites from enterprises. Microorganisms increase rapidly in humid and dirty ambients. We have started to preventive medicine harmful microorganisms leaving hungry and thirsty. Here, the "dry and clean" principle, which is the basic rule of the herd management, comes to the forefront. If there is a fertilizer management problem in the enterprises, the rate of methane gas in the barn will increase, the fight against the carriers will be difficult, the infection factors will not be removed and the water resources will be at risk for heavy metals $(1,5)$.

Hygiene in dairy cattle enterprises is the planning and practice activities for the cleaning of animals and their environment. Bad hygiene standards mean that the disease is spreading rapidly. Hygiene activities cost is lower than treatment costs.

\section{Hygiene practices:}

\section{1-Hygiene of vehicles and equipment}

2-Barn hygiene

3-Cow hygiene

4-Herd hygiene

\section{5-Hygiene of milking unit}

The cleaning score is a indicator used to measure environmental cleaning in dairy farms. These indications are individual cow cleaning, dry and clean cow bedding, SCC and mastitis frequency. Barn cleaning determines the degree of dirty of cattle. In enterprises, the SCC will increase as a result of not doing barn cleaning $(6,7)$. Cook $(8)$ has done research on barn cleaning, animal cleaning and lameness. In this study, the wetness of the barn floor, the bedding material, daily cleaning and the importance of the field per animal are emphasized.

\section{Important indicators of animal welfare level in enterprises}

Welfare refers to the quality of the animal's life. The existence of comfort in animals is determined by measuring welfare. Low performance level in cows means comfort is not good and high performance level means that it is not always a warranty of a good comfort. Dairy cows are responsive to a range of serious welfare problems. These problems are health problems such as lameness, mastitis, infertility, high mortality and culling rates (9).

Physiological and psychological indications are taken into account in evaluating animal welfare (10). In order to be able to make this evaluation, the general condition of the animal (healthy/diseased), yield levels, biochemical, endocrinological and hematological parameters, psychology and behavior should be monitored. Decrease in feed and water consumption, decrease in growth rate and live weight gain, increased mortality in animals, infertility, physical damage (slippery floors, sharp corners, metal structures, etc.), increase in disease frequency, weakening of immune system, increase in drug use, abnormal behavior, stress and decrease of economic life are negative indicators (11-14). The optimal barn conditions for dairy animals (adequate freestall and wandering area, quality bedding material) are an important indicator of welfare. Breeding of cows under optimal environmental conditions inside the barn is also an important indicator of welfare.

Comfort in animals affects natural behavior, physical and psychological health (9). The behavior of the animals is a criterion that determines their level of welfare (12). Animals behave differently in different environmental conditions. Differences in behaviors indicate how adaptive the animals are to the environment. While the animals behave normally in an optimal environment, they behave abnormally under non-optimal environmental conditions (13). The existence of stress in animals can be determined by behavior and clinical parameters (15). Cortisol and plasma glucose levels increase during stress. An increase in the level of glucose is an indication of the existence of stres (16). Dawkins (12) reported that calf mortality rate was low in comfortable environments and that this result was economically advantageous in his study. 


\section{Evaluation of livestock enterprises by scoring method}

Bartussek et al. (17) developed an index called "barn condition score". With this index, scoring can be given to whether the animal is able to free behaviour, the ventilation and lighting status of the barn, the barn floor, social relations and the worker factor. The total barn score is determined according to the result score. Schulte et al. (18) used 5 basic criteria to calculate the animal welfare index in Austria. These; existence of a appropriate area for movement, ventilation-lighting, social behavior, cow bedding and care-management. Soudrum et al. (19) developed a system in which dairy cattle scored from 1-7 using 7 basic criteria in their study. The total of the scores obtained is used in the welfare index.

Hocking et al. (20) reports that the welfare of animals is measured by criteria such as daily live weight gain, behaviors, health and some physiological parameters, yield level, and mortality rate. Seo et al. (21) reported that 5 components were needed to evaluate the animal welfare. These; ease of movement and circulation of the animal, social interaction, freestall field and bedding type, ventilation-lighting in the barn and animal care $(21,22)$. Andrić et al. (23) reported welfare state on each farm was evaluated by relevant measures that indicated insurance of appropriate feeding, housing, health and behavior as basic principles of welfare. Marchewka (24) reported the four principles and 12 animal-based criteria used as guidelines for good welfare according to the Welfare Quality.

In this study, 40 criteria were determined to measure biosecurity and animal welfare in livestock enterprises. These criteria were obtained using various parameters related to biosecurity and animal welfare. These criteria are given in table 1 . The 40-item criteria in the table are based on the following factors:

1-Components building the enterprises (structures and facilities, machine and equipments, livestock forming the herd projection, worker and manager personnel)

\section{2-Biosecurity rules,}

\section{3-Cow comfort.}

The expert will do the evaluation (veterinarian) should be objective, must have educated in this issue, join in collective education and adequate experience. The expert should use an evaluation form for each farm.

This form (Table 1) includes disease/health parameters, behavior parameters, hygiene parameters, parameters related to animal, parameters related to barn and parameters related to the personnel. In Table 1, the criterion for "YES" is 1-scoring, the score for "NO" is 0 -scoring. The score of positive criteria will be collected and the score of enterprises is obtained. Here; 32-40 score are described as an excellent enterprise, 26-31 score as good, 20-25 score as a moderate enterprise and 0-19 score as an inadequate enterprises in terms of biosecurity criteria and animal welfare.

A necessary disinfection tunnel in enterprises is a system that allows livestock transporters, vehicles sent to the quarantine zone or the container of the industrialist who comes to buy the milk. It has become a legal requirement to disinfect vehicles which carry out transport of live animals and animal products according to the legislation on Livestock Disinfection of the General Directorate of Food and Control. The disinfection tunnel is very important in terms of keeping disease agents away from enterprises.

It is important to provide in-service training seminars on biosecurity and animal welfare issues and to provide experienced personnel. Inadequate number of personnel working in the enterprises directly affects animal comfort. It is the environmental factors that affect animal welfare, such as the personnel's enthusiasm, vious, motivation, making love the personnel's job. If the number of personnel in the enterprises is not enough, the performance will decrease, the motivation will decrease and the labor will decrease. As a simple example, the tired worker will neglect the colostrum of the newborn calf in the evening and calf deaths.

It is necessary for the personnel to perform a porter's examination before starting work, to repeat this examination every 6 months and to keep the results on the management structure (documentary record). This document is also a necessary document to get "free document from disease". This indicator is important in terms of keeping the disease agents away. Factors that humidity the ambients in which the animals are located will cause bacteria to replicate and it will not be possible to keep disease agents away.

These factors;

a-Negativities are factors that humidify the ambient, the deficiency of a land tendency of $10-15 \%$ in enterprises, absence of chimneys at the highest scoring of the barn, full of automatic watering etc. problems.

b-It is a desirable character that the enterprises land is tendency, inefficient, barren and uninhabited land. Over time, ground water will land on the soil and will form a continuous watery ambient.

c-If the chimney is not at the highest scoring of the barn, the warming air expands and circulate the highest scoring of the barn. Condenses at the highest scoring, it builds up water in the barn.

d-Automatic watering must be filled with water. If the automatic watering is full of water, the water with the volume of the animal's mouth will accumulate on the floor.

Cattle can drink up to 80-150 liters of water a day. Therefore, automatic watering is required for welfare. Not enough field per animal and reduced volume of fresh air will cause respiratory diseases. 
Table 1. The form used to evaluate of dairy cattle enterprises by scoring method

\begin{tabular}{|c|c|c|c|}
\hline Number & Criteria & Yes & No \\
\hline 1 & Is it surrounded around the enterprises (wire, fence, knitted wall, curtain wall etc.)? & 1 & 0 \\
\hline 2 & Is there a disinfectant pit for persons and a disinfection tunnel for vehicles at enterprises entry? & 1 & 0 \\
\hline 3 & Is there a administration unit in enterprises? & 1 & 0 \\
\hline 4 & Is there a security camera at enterprises entry, barn and milking unit? & 1 & 0 \\
\hline 5 & Is there a quarantine unit in the enterprises? & 1 & 0 \\
\hline 6 & Does the enterprises field have a $10-15 \%$ slope? & 1 & 0 \\
\hline 7 & Is the number of personnel working enough? & 1 & 0 \\
\hline 8 & Is the porter's examination being performed for the new employee? & 1 & 0 \\
\hline 9 & Are the personnel clothes different inside and outside farms? & 1 & 0 \\
\hline 10 & Is there a distance of 40 meters between two shelters? & 1 & 0 \\
\hline 11 & Does the adviser manager work in the enterprise? & 1 & 0 \\
\hline 12 & Is there struggle with animals of carrier (exotic animal, dog, cat, bird, flies, insect, rodent, mice etc.)? & 1 & 0 \\
\hline 13 & Is does daily cleaning in enterprises? (In terms of hygiene) & 1 & 0 \\
\hline 14 & Are vaccination practices performed in line with the vaccination calendar timely? & 1 & 0 \\
\hline 15 & Is the barn floor ideal? & 1 & 0 \\
\hline 16 & Does the freestall dimensions and freestall threshold have ideal measure? & 1 & 0 \\
\hline 17 & Is there a tendency of $1-3 \%$ at the freestall? & 1 & 0 \\
\hline 18 & Is the bedding material in barn appropriate for the relaxation of the animals? & 1 & 0 \\
\hline 19 & Is 2 liters of colostrum within the first 6 hours is given to newborn calves? & 1 & 0 \\
\hline 20 & Is mastitis rate less than $5 \%$ in enterprises? & 1 & 0 \\
\hline 21 & Is calf mortality rate is less than $5 \%$ in enterprises? & 1 & 0 \\
\hline 22 & Is there enough number of calf paddocks in the barn and calf clubs outside the barn? & 1 & 0 \\
\hline 23 & Is there a infirmary and birth unit? & 1 & 0 \\
\hline 24 & Have the animals been tested for Brucella and tuberculosis? & 1 & 0 \\
\hline 25 & Is there a foot bath at the entry and exit of the milking unit? & 1 & 0 \\
\hline 26 & Is the milking unit 500-1000 meter away from the barn? & 1 & 0 \\
\hline 27 & Is there enough per animal area? & 1 & 0 \\
\hline 28 & It does the eyes burn because of methane gas and ammonia in the barn? & 1 & 0 \\
\hline 29 & Is there enough light to read books in the barn? & 1 & 0 \\
\hline 30 & Are cooling applications applied against heat stress? & 1 & 0 \\
\hline 31 & Does the enterprises have a thermometer, hygrometer, and temperature $\mathrm{x}$ humidity index card? & 1 & 0 \\
\hline 32 & Is the correct care and feeding done according to the rationing program? & 1 & 0 \\
\hline 33 & Is there an automatic brush for 50 cattle? & 1 & 0 \\
\hline 34 & Is a pedometer used for cows in enterprises? & 1 & 0 \\
\hline 35 & Can the animals show specific behavior all? & 1 & 0 \\
\hline 36 & Are animals weighed? ( 15 days or once a month) & 1 & 0 \\
\hline 37 & Is the generator running in enterprises? (in case of power failure) & 1 & 0 \\
\hline 38 & Is the chimney at the highest of the barn? & 1 & 0 \\
\hline 39 & Are there automatic watering in the barn? & 1 & 0 \\
\hline 40 & Are all data recorded on the enterprise computer? & 1 & 0 \\
\hline
\end{tabular}


Methane gas from the animal's faeces and ammonia gas from the urine are the factors that cause eye disease and lung diseases. Good ventilation is required to remove harmful gases (methane, ammonia, $\mathrm{CO}_{2}$, etc.) inside the barn. For this purpose, at least $1 / 20$ window area of floor area and at least $1 / 100$ chimney area of floor area should be planned. In addition, optimal temperature and relative humidity in the barn are important for minimizing stress factors (1).

The barn floor is an effective indicator on cow comfort. This floor can cause traumatic damage, laminitis, mastitis and metabolic diseases. Freestall dimensions and freestall threshold in the barn must have optimum dimensions. Cows should be as comfortable as 12-14 hours at the freestall. If cows do not stay in the freestall within the ideal time, the dry matter consumption decreases. Therefore, milk production decreases. Bedding material is an important factor in udder health, nail, foot and leg problems.

\section{Health Parameters (Criteria for keeping disease agents away):}

The daily cleaning of urine and fertilizer channel are important for the removal of harmful agents to the respiratory system of the animals. In Animals, methane gas from the feces and ammonia gas from the urine are factors that burn the eyes and cause lung diseases. The existence of the foot bath at the entry and exit of the milking unit is important for keeping the disease agents away. In milking units, it is important to follow the required rules before, during and after milking, to determine the total bacteria and SHS in milk and to take required preventions for keeping the disease agents away. The dead animals should be sent to the rendering facilities or buried in the medical waste unit (destruction pit). Waste should be covered with quicklime. For the hygienic and quality milk production, it is important to apply the fertilizer management program in terms of herd health management.

Natural and artificial vaccinations should be applied timely to strengthen the immune system. If enough colostrum can not be given by farmers, the calf mortality rates will increase. The breeding of female calves, the future's highly productive dairy cow is an important step in dairy cattle breeding.

In animals, weighing machine is required to determine live weight gain. If the daily live weight gain is low in animals, there is a problem (parasites, hierarchical order, chronic diseases, etc.). This is important for animal health.

Veterinary health costs are related to the number of diseases in the enterprises and the minority or multiplicity of drugs used. These costs include veterinary examination fees and payments for medicines. The ratio of these costs in total enterprise costs is a criterion that shows the level of application of biosecurity rules in the enterprise.

\section{CONCLUSION}

It is defined as a good enterprise that thinks the motivation of the personnel, the welfare of the animals, the profit of the farmers and consumers' quality of life. As the cows can be evaluated over 100 scoring with physical type scoring, the evaluation of the enterprises with the scoring system should be made widespread. Thus, it is possible to have a sustainable enterprise structure in which with long-lived cows. To make these evaluation applicable, there is a need for a specific time and expert personnel. If the criteria that determine the level of biosecurity and animal welfare in each enterprise are considered by the adviser veterinarian, this study will contribute more to the practical life. This 40 -scoring evaluation, which should be applied in dairy cattle farms, should be planned to compose the minimal stress on both animals and personel (25).

\section{REFERENCES}

1. Uğur F. Sığır Yetiştirme (Ders Kitabı). Çanakkale Onsekiz Mart Üniversitesi Yayınlar1 No: 117. Birinci bask1. Pozitif Matbaa. 2014; ISBN: 978-605-4222-36-0.

2. Anonymous. Gıda, Tarım ve Hayvancilık Bakanlığı, Gıda ve Kontrol Genel Müdürlügü, hastalıktan ari işletmeler, Genelge 2018/1, https://www.tarim.gov.tr/Belgeler/Mevzuat/Genelgeler/gkgm/AriIsletmeOnayliCiftlik.pdf, (Erişim 11.09.2018).

3. Antalyalı A. Avrupa Birliği ve Türkiye'de hayvan refahı uygulamaları. AB Uzmanlık Tezi, Tarım ve Köyişleri Bakanlığı Dış İlişkiler ve AB Koordinasyon Dairesi Başkanlığı, 2007; Ankara.

4. Erşan, I., 2018. Avrupa Birliği hayvan hastalıkları politikasındaki gelişmeler ve yeni yasa teklifi, https://www.tarim. gov.tr/ABDGM/Belgeler $/ \% \mathrm{C} 4 \% \mathrm{~B} 0 \mathrm{DAR} \% \mathrm{C} 4 \% \mathrm{~B} 0 \% 20$ $\%$ C4\%B $\% \%$ C5\%9ELER/Uzmanl $\%$ C4\%B1k\%20Tez $\% 20$ Eyl\%C3\%BCl\%202015/Is\%C4\%B1k\%20Ersan.pdf, (Erişim 16.08.2018).

5. Aksoy FT. Sürü Sağllğı ve Biyogüvenlik, http://www.ciftlikdergisi.com.tr/suru-sagligi-ve-biyoguvenlik.html (Erişim 18.05.2018).

6. Ellis KA, Mihm M, Innocent G, Cripps P, McLean WG, Howard CV, Grove-White DG. Assessing the Relationship Between Dairy Cow Cleanliness and Bulk Milk Hygiene on Organic and Conventional Farms. Proceedings of the 11th International Symposium on Veterinary Epidemiology and Economics, 2006.

7. Wolf A. A Welfare Assessment System for Dairy Cows on Pasture and The Comparison to a Welfare Scoring System For Cows in Cubicles. Research Project Veterinary Medicine, University of Utrecht, 2009.

8. Cook NB. The influence of barn design on dairy cow hygiene, lameness and udder health, Clinical Assistant Professor in Food Animal Production Medicine, Univeristy of Wisconsin-Madison, School of Veterinary Medicine, Madison, WI 53706, 2004.

9. Keeling L, Jensen P. Behavioural Disturbances, Stress and Welfare. In: The Ethology of Domectic Animals, An Introductory Text. Ed. by P. Jensen. CABI Publishing, 2002; 79-99.

10. Swanson JC. Farm Animal Well-Being and Intensive Production Systems. J Anim Sci. 1995;73:2744-2751. 
11. Broom DM. Welfare stress and the evolution of feelings. Adv Study Behav. 1998;27:371-403.

12. Dawkins MS. Animal Welfare and Efficient Farming: is Conflict Inevitable?, DOI:10.1071/AN15383, 2016.

13. Duncan IJH, Poole TB. Promoting the welfare of farm and captive animals, In Managing the behaviour of animals, Edited by P. Monaghan and D. Wood-Gush, Chapman and Hall, Cambridge, UK, 1990.

14. Vetter S, Vasa L, Ózsvari L. Economic Aspects of Animal Welfare, Acta Polytechnica Hungarica, 2014;11:119-134.

15. Rowan AN. The Concept of Animal Welfare and Animal Suffering. In: Animal Alternatives, Welfare and Ethics. Eds: L.F.M. van Zuphten and M. Balls. pp.157-168. Published: Elsevier Sci. BV, Amsterdam, 1997.

16. Sanhouri AA, Jones RS, Dobson H. Pentobarbitone inhibits the stress response to transport in male goats. Br Vet J, 1991;147:42-48.

17. Bartussek H, Leeb CH, Held S. Animal needs index for cattle, Federal Research Institute for Agriculture in Alpine Regions, BAL Gumpenstein A 8952, Austria, 2000.

18. Schulte R, Earley B, Wouw S, Culleton N. Animal Welfare - Development of methodology for its assessment. Farm \& Food Autumn, 1998.

19. Soudrum A, Andersson R, Foster G. Tiergerechtheitsindex-200, Institut für Organischen Landbau, Bonn, 1994.

20. Hocking PM, Channing CE, Robertson GW, Edmond A, Jones RB. Between breed genetic variation for welfare-related behavioural traits in domestic fowl. Appl Anim Behav Sci, 2004;89:85-105.

21. Seo T, Date K, Daigo T, Kashiwamura F, Sato S. Welfare Assessment on Japanese Dairy Farms Using the Animal Needs Index, UK, Universities Federation for Animal Welfare, 2007; 16: 221-223.

22. Bartussek H. An Historical Account of the Development of the Animal Needs Index ANI-35L as Part of the Attempt to Promote and Regulate Farm Animal Welfare in Austria: An Example of the Interaction Between Animal Welfare Science and Society, 2001, DOI:10.1080/090647001316923036.

23. Andrić DO, Hristov S, Petrović MM, Pantelić V, Nikšić D, Petrović VC, Stanković B. The State of Welfare on Serbian Dairy Farms, Biotechnology in Animal Husbandry 32 (3), p 239-249, 2016, DOI: 10.2298/BAH1603239O.

24. Marchewka J. Development of practical methodology and indicators for on-farm animal welfare assessment, Thesis directed by: Dr. Inma Estevez, Department of Zoology and Animal Cellular Biology, Faculty of Science and Technology, University of Basque Country. Vitoria Gasteiz, 2015.

25. Polsky L, Marina AG. Effects of heat stress on dairy cattle welfare, J. Dairy Sci 2017;100:8645-8657. 